\title{
Histone H1x
}

National Cancer Institute

\section{Source}

National Cancer Institute. Histone H1x. NCI Thesaurus. Code C162815.

Histone $\mathrm{H} 1 \times(213 \mathrm{aa}, \sim 22 \mathrm{kDa})$ is encoded by the human $\mathrm{H} 1-10$ gene. This protein is involved in DNA condensation. 